\title{
Relaksasi Nafas Dalam Menurunkan Kecemasan Pasien Pre Operasi Bedah Abdomen
}

\author{
Agung Octa Nihando Rokawie ${ }^{1}$, Sulastri $^{2}$, Anita $^{3}$ \\ 1,2,3 Jurusan Keperawatan, Politeknik Kesehatan Tanjungkarang \\ Email: agung.nihando@gmail.com
}

\begin{abstract}
Deep Breath Relaxation Therapy on Decreasing Anxiety Level in Patients With Pre Operative Abdominal Surgery. Anxiety is a subjective experience of a person and an emotion like an uncertain sense of concern. One of the anxiety stressors is surgery. The objective of the study was to know the effect of deep breath relaxation therapy on decreasing anxiety level in patients with pre operative abdominal surgery. This research uses pre experimental design approach with one group pretest posttest design. This research was held on April 2017 at Surgery Room of Jendral Ahmad Yani Metro City. Sampling technique using non-probability sampling by purposive sampling, obtained as many as 32 respondents based on the calculation using the formula of the sample proportion estimation. Bivariate analysis using paired t test (paired sample $t$ test). The results of this study showed anxiety level in patients with pre operative abdominal surgery before being given deep breath relaxation therapy has an average anxiety index score of 54.59 (moderate anxiety) and anxiety level in patients with preoperative abdominal surgery after being given deep breath relaxation therapy has an anxiety index score of 49.56 (mild anxiety) and a decrease of 5.03. The results of this study are expected to be a reference to the use of deep breath relaxation therapy in accordance Standard Operational Procedures to decrease anxiety levels in pre operative patients using Leaflet.
\end{abstract}

Keywords: Relaxation therapy, Anxiety levels, Preoperative abdominal surgery

\begin{abstract}
Abstrak: Relaksasi Nafas Dalam Menurunkan Kecemasan Pasien Pre Operasi Bedah Abdomen. Kecemasan adalah pengalaman subjektif dari seseorang dan merupakan sebuah emosi seperti rasa kekhawatiran yang tidak jelas. Salah satu stressor kecemasan adalah tindakan operasi atau pembedahan. Tujuan penelitian diketahuinya pengaruh terapi relaksasi nafas dalam terhadap penurunan tingkat kecemasan pada pasien pre operasi bedah abdomen. Penelitian ini menggunakan pendekatan pre experimental design dengan rancangan one group pretest posttest. Penelitian ini dilakukan pada bulan April 2017 di Ruang Bedah RSUD Jendral Ahmad Yani Metro. Teknik sampling menggunakan non probability sampling secara purposive sampling, didapatkan sebanyak 32 responden berdasarkan perhitungan menggunakan rumus besar sampel estimasi proporsi. Analisa bivariate menggunakan uji t berpasangan (paired sample $t$ test). Hasil penelitian diperoleh tingkat kecemasan pada pasien pre operasi bedah abdomen sebelum diberikan terapi relaksasi nafas dalam mempunyai rata-rata skor indeks kecemasan 54,59 (kecemasan sedang) dan tingkat kecemasan pada pasien pre operasi bedah abdomen setelah diberikan terapi relaksasi nafas dalam mempunyai rata-rata skor indeks kecemasan 49,56 (kecemasan ringan) dan terjadi penurunan sebesar 5,03. Saran penelitian ini diharapkan dapat menjadi rujukan penggunaan terapi relaksasi nafas dalam sesuai Standar Operasional Prosedur untuk mengurangi tingkat kecemasan pada pasien pre operasi dengan menggunakan media Leaflet.
\end{abstract}

Kata kunci: Terapi relaksasi, Tingkat kecemasan, Pre operasi bedah abdomen

Operasi atau pembedahan merupakan salah satu tindakan medis yang penting dalam pelayanan kesehatan dan bertujuan untuk menyelamatkan nyawa, mencegah kecacatan, dan komplikasi (Puspita, Armiyati, \& Arif, 2014). Salah satu jenis tindakan operasi adalah bedah abdomen.

Penelitian di 56 negara dari 192 negara anggota World Health Organization (WHO) tahun 2004 diperkirakan 234,2 juta prosedur operasi dilakukan setiap tahun berpotensi komplikasi dan kematian (Puspita, Armiyati, \& Arif, 2014). Sehingga prosedur operasi secara tidak langsung akan mempengaruhi psikologi pasien.

Prosedur operasi akan memberikan suatu reaksi emosional bagi pasien seperti ketakutan atau perasaan tidak tenang, marah, dan kekhawatiran (Muttaqin \& Sari, 2009). Persiapan mental merupakan hal yang tidak kalah pentingnya 
dalam proses persiapan operasi karena mental pasien yang tidak siap dapat mempengaruhi kondisi fisiknya. Masalah mental yang biasa muncul pada pasien pre operasi adalah kecemasan.

Kecemasan adalah kekhawatiran yang tidak jelas dan menyebar, yang berkaitan dengan perasaan tidak pasti dan tidak berdaya. Keadaan emosi ini tidak memiliki objek yang spesifik. Kecemasan dialami secara subjektif dan didokumentasikan secara interpersonal. Kecemasan berbeda dengan rasa takut, yang merupakan penilaian intelektual terhadap bahaya. Kecemasan adalah respons emosional terhadap penilaian tersebut. Kapasitas untuk menjadi cemas diperlukan untuk bertahan hidup. Gangguan kecemasan merupakan masalah psikiatri yang paling sering terjadi di Amerika Serikat (Stuart, 2006).

Kecemasan adalah sebuah emosi dan pengalaman subjektif dari seseorang. Pengertian lain cemas adalah suatu keadaan yang membuat seseorang tidak nyaman dan terbagi dalam tingkatan. Jadi, cemas berkaitan dengan perasaan yang tidak pasti dan tidak berdaya (Kusumawati \& Hartono, 2011).

Kecemasan adalah diagnosa keperawatan utama yang dialami pasien pre operasi. Kekhawatiran mengenai kehilangan waktu kerja, kemungkinan kehilangan pekerjaan, tanggung jawab mendukung keluarga, dan ancaman ketidakmampuan permanen yang lebih jauh, memperberat ketegangan emosional yang sangat berat yang diciptakan oleh prospek pembedahan. Kekhawatiran nyata yang lebih ringan dapat terjadi karena pengalaman sebelumnya dengan sistem perawatan kesehatan dan orang-orang yang dikenal pasien dengan kondisi yang sama. Akibatnya, perawat harus memberikan dorongan untuk mengungkapkan, dan harus mendengarkan, harus memahami, dan memberikan informasi yang membantu menyingkirkan kekhawatiran tersebut. Keluasan reaksi pasien pada banyak faktor, meliputi ketidaknyamanan dan perubahan-perubahan yang diantisipasi-baik fisik, finansial, psikologis, spiritual, atau sosial-dan hasil akhir pembedahan yang diharapkan. Akankah pembedahan tersebut memperbaiki keadaan. Akankah pembedahan tersebut mengakibatkan ketidakmampuan. Apakah ini hanya merupakan tindakan sementara dalam kondisi kronik (Smeltzer \& Bare, 2002).

Kecemasan perlu mendapat perhatian dan intervensi keperawatan karena keadaan emosional pasien yang akan berpengaruh kepada fungsi tubuh pasien menjelang operasi.
Kecemasan yang tinggi dapat memberikan efek dalam mempengaruhi fungsi fisiologis tubuh yang ditandai dengan adanya peningkatan tekanan darah, peningkatan frekuensi nadi, peningkatan frekuensi napas (Muttaqin \& Sari, 2009). Karena dengan adanya tanda-tanda tersebut maka biasanya operasi akan ditunda oleh dokter sehingga menghambat penyembuhan penyakit pada klien. Disini peran perawat sangatlah diperlukan untuk melakukan intervensi kepada pasien dari pre hingga post operasi. Perawat dapat melakukan terapi-terapi seperti terapi relaksasi, distraksi, meditasi, imajinasi. Dalam penelitian ini peneliti memilih melakukan terapi relaksasi.

Terapi relaksasi adalah tehnik yang didasarkan kepada keyakinan bahwa tubuh berespon pada ansietas yang merangsang pikiran karena nyeri atau kondisi penyakitnya. Teknik relaksasi dapat menurunkan ketegangan fisiologis. Teknik ini dapat dilakukan dengan kepala ditopang dalam posisi berbaring atau duduk di kursi. Hal utama yang dibutuhkan dalam pelaksanaan teknik relaksasi adalah klien dengan posisi yang nyaman, klien dengan pikiran yang beristirahat, dan lingkungan yang tenang (Asmadi, 2009).

Terapi relaksasi memiliki berbagai macam yaitu latihan nafas dalam, masase, relaksasi progresif, imajinasi, biofeedback, yoga, meditasi, sentuhan terapeutik, terapi musik, serta humor dan tawa (Kozier, Erb, Berman, \& Snyder, 2010). Teknik relaksasi yang lebih dipilih untuk menurunkan kecemasan pada pasien pre operasi yaitu teknik relaksasi nafas dalam. Dalam terapannya terapi relaksasi nafas dalam lebih mudah dipelajari dan diterapkan oleh para pasien nantinya, serta keuntungannya menggunakan terapi nafas dalam ini adalah waktu dan dana yang dikeluarkan tidak terlalu banyak dibandingkan terapi relaksasi yang lain.

Penelitian Rafsanjani (2015) Pasien di Ruang Rawat Inap RSUD Dr. H. Abdul Moeloek Provinsi Lampung yang akan menjalani operasi sebagian besar mengalami kecemasan dan menunjukkan bahwa dari 26 orang responden terdapat 3 orang yang memiliki kecemasan dalam kategori ringan, 10 orang dalam kategori sedang, dan 7 orang dalam kategori berat.

Hasil pre survey yang dilakukan oleh peneliti di RSUD Dr. H. Abdul Moeloek Provinsi Lampung didapatkan jumlah pasien pre operasi pada bulan Desember 2016 di ruang Kutilang terdapat 58 pasien, 18 diantaranya merupakan pasien pembedahan laparatomi, dan di ruang Mawar terdapat 60 pasien pre operasi, 6 diantaranya merupakan pasien pembedahan laparatomi. 
Hasil pre survey yang dilakukan oleh peneliti di RSUD Jendral Ahmad Yani Metro didapatkan jumlah pasien pre operasi pada bulan Februari 2017 di ruang Bedah terdapat 124 pasien, 35 diantaranya merupakan pasien pembedahan laparatomi.

Fenomena yang ditemukan di rumah sakit menunjukkan bahwa sebagian besar pasien yang akan menjalani operasi merasa khawatir dan mengatakan takut akan terjadinya cacat, takut tidak sembuh, dan takut meninggal. Penatalaksanaan keperawatan mandiri yang lebih dipilih untuk mengatasinya yaitu dengan terapi relaksasi nafas dalam. Oleh karena itu peneliti tertarik untuk melakukan penelitian tentang pengaruh terapi relaksasi nafas dalam terhadap penurunan tingkat kecemasan pada pasien pre operasi bedah abdomen di Ruang Bedah RSUD Jendral Ahmad Yani Metro Tahun 2017.

\section{METODE}

Jenis penelitian ini adalah penelitian kuantitatif dengan pre experimental design yang diperluas dengan rancangan one group pretestposttest. Penelitian ini akan memberikan intervensi pada subyek dengan cara melakukan observasi tingkat kecemasan pasien pre operasi (pretest) yang dilakukan minimal sehari sebelum tindakan operasi menggunakan lembar penilaian kecemasan Zung Self-Rating Anxiety Scale pada responden yang sesuai dengan kriteria inklusi dan telah menandatangani informed consent. Setelah dilakukan penilaian kecemasan, pasien diajarkan terapi relaksasi nafas dalam. Setelah itu dilakukan penilaian ulang tingkat kecemasan (posttest) yang dilakukan minimal 3 jam sebelum tindakan operasi.

Populasi dalam penelitian adalah semua pasien pre operasi bedah abdomen dengan masalah kecemasan pre operasi di Ruang Bedah RSUD Jendral Ahmad Yani Metro sebanyak 35 pasien dengan besar sampel 32 pasien.

Hipotesis penelitian ini yaitu ada pengaruh terapi relaksasi nafas dalam terhadap penurunan tingkat kecemasan pada pasien pre operasi bedah abdomen di Ruang Bedah RSUD Jendral Ahmad Yani Metro.

Bentuk instrumen yang digunakan dalam pengumpulan data tingkat kecemasan pada pasien pre operasi bedah abdomen menggunakan instrumen berupa kuesioner instrumen kecemasan Zung SelfRating Anxiety Scale.

\section{HASIL}

\section{Jenis Kelamin}

Tabel 1. Karakteristik Responden Berdasarkan Jenis Kelamin

\begin{tabular}{lcc}
\hline Jenis Kelamin & n & \% \\
\hline Laki-laki & 16 & 50,0 \\
Perempuan & 16 & 50,0 \\
\hline Total & $\mathbf{3 2}$ & $\mathbf{1 0 0}$ \\
\hline
\end{tabular}

Berdasarkan tabel 1 diketahui bahwa jumlah responden laki-laki adalah 16 responden $(50,0 \%)$ dan perempuan adalah 16 responden $(50,0 \%)$.

\section{Usia}

Tabel 2. Karakteristik Responden Berdasarkan Usia

\begin{tabular}{clrr}
\hline & Usia & \multicolumn{1}{c}{ n } & \multicolumn{1}{c}{$\%$} \\
\hline $18-25$ & (Dewasa muda) & 10 & 31,3 \\
$26-35$ & (Dewasa awal) & 3 & 9,4 \\
$36-45$ & (Dewasa akhir) & 3 & 9,4 \\
$46-55$ & (Lansia awal) & 7 & 21,8 \\
$56-65$ & (Lansia akhir) & 4 & 12,5 \\
\hline$>65$ & (Manula) & 5 & 15,6 \\
\hline Total & & $\mathbf{3 2}$ & $\mathbf{1 0 0}$ \\
\hline
\end{tabular}

Berdasarkan tabel 2 diketahui bahwa usia responden terbanyak adalah usia 18-25 tahun (Dewasa muda) sebanyak 10 responden $(31,3 \%)$.

\section{Jenjang Pendidikan}

Tabel 3. Karakteristik Responden Berdasarkan Jenjang Pendidikan

\begin{tabular}{lrl}
\hline \multicolumn{1}{c}{ Jenjang Pendidikan } & \multicolumn{1}{c}{ n } & \% \\
\hline Pendidikan Dasar & 17 & 53,1 \\
Pendidikan Menengah & 11 & 34,4 \\
Pendidikan Tinggi & 4 & 12,5 \\
\hline Total & $\mathbf{3 2}$ & $\mathbf{1 0 0}$ \\
\hline
\end{tabular}

Berdasarkan tabel 3 diketahui bahwa jenjang pendidikan responden terbanyak adalah Pendidikan Dasar sebanyak 17 responden (53,1\%), kemudian diikuti Pendidikan Menengah sebanyak 11 responden $(34,4 \%)$, dan Pendidikan Tinggi sebanyak 4 responden $(12,5 \%)$. 


\section{Pekerjaan}

Tabel 4. Karakteristik Responden Berdasarkan Pekerjaan

\begin{tabular}{lcc}
\hline \multicolumn{1}{c}{ Pekerjaan } & n & \% \\
\hline IRT & 7 & 21,8 \\
Wiraswasta & 6 & 18,8 \\
Petani & 9 & 28,1 \\
Pelajar & 6 & 18,8 \\
Buruh & 1 & 3,1 \\
Pegawai Swasta & 3 & 9,4 \\
\hline Total & $\mathbf{3 2}$ & $\mathbf{1 0 0}$ \\
\hline
\end{tabular}

Berdasarkan tabel 4 diketahui bahwa pekerjaan responden terbanyak adalah Petani sebanyak 9 responden $(28,1 \%)$, IRT sebanyak 7 responden $(21,8 \%)$, kemudian diikuti Wiraswasta sebanyak 6 responden $(18,8 \%)$, Pelajar sebanyak 6 responden $(18,8 \%)$, Pegawai swasta sebanyak 3 responden $(9,4 \%)$, dan Buruh sebanyak 1 responden $(3,1 \%)$.

\section{Rata-rata Skor Indeks Kecemasan}

Tabel 5. Rata-rata Skor Indeks Kecemasan Pre Operasi Sebelum dan Setelah Diberikan Tindakan Relaksasi Nafas Dalam

\begin{tabular}{lcc}
\hline \multicolumn{1}{c}{ Kriteria } & Sebelum & Sesudah \\
\hline Frekuensi (n) & 32 & 32 \\
Mean & 54,59 & 49,56 \\
Median & 54,50 & 50,50 \\
Standar Deviasi (SD) & 4,758 & 4,600 \\
Minimum & 46 & 41 \\
Maksimum & 65 & 59 \\
\hline
\end{tabular}

Berdasarkan tabel 5 diketahui bahwa ratarata skor indeks kecemasan pre operasi sebelum diberikan tindakan relaksasi nafas dalam adalah 54,59, dan setelah diberikan tindakan relaksasi nafas dalam adalah 49,56.

\section{Perbedaan Rata-rata Skor Indeks Kecemasan}

Tabel 6. Perbedaan Rata-rata Skor Indeks Kecemasan Pre Operasi Sebelum dan Setelah Diberikan Tindakan Relaksasi Nafas Dalam

\begin{tabular}{l|c|c|c|c}
\hline \multicolumn{1}{c|}{ Variabel } & Mean & SD & p-value & n \\
\hline $\begin{array}{l}\text { Rata- rata skor } \\
\text { indeks kecemasan } \\
\text { sebelum terapi } \\
\text { relaksasi }\end{array}$ & 54,59 & 4,758 & & \\
\hline $\begin{array}{l}\text { Rata- rata skor } \\
\text { indeks kecemasan } \\
\text { setelah terapi } \\
\text { relaksasi }\end{array}$ & 49,56 & 4,600 & & \\
\hline
\end{tabular}

Berdasarkan tabel 6 dapat disimpulkan bahwa rata-rata skor indeks kecemasan pre operasi sebelum diberikan tindakan relaksasi nafas dalam adalah 54,59. Pada pengukuran ratarata skor indeks kecemasan setelah diberikan tindakan relaksasi nafas dalam didapatkan ratarata kecemasan 49,56, nilai perbedaan mean antara kecemasan sebelum dan sesudah diberikan tindakan relaksasi nafas dalam adalah 5,03. Hasil uji statistik dengan uji t-dependent didapatkan perhitungan $p$-value $(0,000)<\alpha \quad(0.05) \quad$ yang berarti ha diterima sehingga dapat disimpulkan bahwa terdapat perbedaan rata-rata skor indeks kecemasan sebelum dan sesudah dilakukan terapi relaksasi nafas dalam pada pasien pre operasi bedah abdomen.

\section{PEMBAHASAN}

Kecemasan adalah kekhawatiran yang tidak jelas dan menyebar, yang berkaitan dengan perasaan tidak pasti dan tidak berdaya. Keadaan emosi ini tidak memliliki objek yang spesifik. Kecemasan dialami secara subjektif dan dikomunikasikan secara interpersonal. Kecemasan berbeda dengan rasa takut, yang merupakan penilaian intelektual terhadap bahaya. Kecemasan adalah respon emosional terhadap penilaian tersebut. Gangguan kecemasan merupakan masalah psikiatri yang paling sering terjadi di Amerika Serikat (Stuart, 2006).

Cemas (ansietas) adalah sebuah emosi dan pengalaman subjektif dari seseorang. Pengertian lain cemas adalah suatu keadaan yang membuat seseorang tidak nyaman dan terbagi dalam tingkatan. Jadi, cemas berkaitan dengan perasaan yang tidak pasti dan tidak berdaya (Kusumawati \& Hartono, 2011).

Berdasarkan hasil penelitian diketahui bahwa tingkat kecemasan pasien pre operasi dari 32 responden di Ruang Bedah RSUD Jendral Ahmad Yani Metro adalah tidak ada kecemasan 0 responden $(0 \%)$ menjadi 6 responden $(18,8 \%)$, kecemasan ringan 11 responden $(34,4 \%)$ menjadi 17 responden $(53,1 \%)$, kecemasan sedang 18 responden $(56,2 \%)$ menjadi 9 responden $(28,1 \%)$, kecemasan berat 3 responden $(9,4 \%)$ menjadi tidak ada responden yang mengalami kecemasan berat $(0 \%)$.

Berdasarkan penelitian ini diketahui bahwa rata-rata skor indeks kecemasan pre operasi sebelum diberikan tindakan relaksasi nafas dalam adalah 54,59. Pada pengukuran rata-rata skor indeks kecemasan setelah diberikan tindakan relaksasi nafas dalam didapatkan rata-rata kecemasan 49,56, nilai perbedaan mean antara 
kecemasan sebelum dan sesudah diberikan tindakan relaksasi nafas dalam adalah 5,03. Hasil uji statistik dengan uji t-dependent didapatkan perhitungan $p$-value $(0,000)<\alpha \quad(0.05)$ yang berarti ha diterima sehingga dapat disimpulkan bahwa terdapat perbedaan rata-rata skor indeks kecemasan sebelum dan sesudah dilakukan terapi relaksasi nafas dalam pada pasien pre operasi bedah abdomen.

Hal ini diperkuat dengan teori Smeltzer \& Bare (2002) yang menyatakan bahwa tujuan teknik relaksasi napas dalam adalah untuk meningkatkan ventilasi alveoli, memelihara pertukaran gas, mencegah atelektasi paru, meningkatkan efesiensi batuk, mengurangi stress, baik stress fisik maupun emosional yaitu menurunkan intensitas nyeri dan menurunkan kecemasan.

Hasil ini sesuai dengan penelitian Rafsanjani (2015) Kecemasan pasien pre operasi kelompok eksperimen, dari 26 responden diperoleh hasil kecemasan berat; dari $27 \%$ menjadi 15,3\%, kecemasan sedang; dari $38,4 \%$ menjadi $30,7 \%$, kecemasan ringan; dari $11,5 \%$ menjadi $27 \%$, tidak ada kecemasan; dari $23,1 \%$ menjadi 27\%. Maka dapat disimpulkan ada perbedaan antara tingkat kecemasan sebelum dan sesudah dilakukan terapi relaksasi.

Penelitian ini juga terkait dengan penelitian Sudarsih (2012) Diperoleh tingkat kecemasan pada pasien pre operasi appendisitis di Ruang Perawatan Rumah Sakit Imanuel sebelum diberikan teknik relaksasi nafas dalam mempunyai nilai rata-rata 33,6 (ringan sampai sedang) dan tingkat kecemasan pada pasien pre operasi sesudah diberikan teknik relaksasi nafas dalam mempunyai nilai rata-rata 21,4 (tidak cemas) dan terjadi penurunan sebesar 12,2. Hal ini dapat disimpulkan bahwa pemberian teknik relaksasi nafas dalam mempengaruhi penurunan tingkat kecemasan.

Penelitian ini semua responden mengalami tindakan pembedahan untuk pertama kalinya, hal ini mungkin yang menyebabkan responden mengalami kecemasan karena ketidaktahuan akan pengalaman pembedahan. Hal ini diperkuat dengan teori Muttaqin \& Sari (2009) yang menyatakan bahwa pasien yang akan menjalani operasi akan mengalami dampak psikologis. Berbagai dampak psikologis yang dapat muncul adalah kecemasan yang terekspresikan dalam berbagai bentuk seperti marah, menolak, atau apatis terhadap kegiatan keperawatan. Semua itu akibat dari adanya ketidaktahuan akan pengalaman pembedahan.

Penelitian ini diketahui bahwa kecemasan terbanyak dialami oleh responden yang berumur
18-25 tahun (Dewasa muda) sebanyak 10 responden $(31,3 \%$.). Masa dewasa adalah masa yang penuh dengan ketegangan emosional. Ketegangan emosional seringkali ditampakkan dalam kekhawatiran. Kekhawatiran yang timbul pada umumnya bergantung pada tercapainya penyesuaian terhadap persoalan yang dihadapi pada saat tertentu. Ketidakmampuan dalam mengatasi masalah akan menyebabkan gangguan emosional (Puspita, Armiyati, \& Arif, 2014).

Penelitian ini diketahui bahwa kecemasan terbanyak dialami oleh responden dengan tingkat Pendidikan Dasar sebanyak 17 responden $(53,1 \%)$. Notoatmodjo (2010) menyatakan bahwa semakin tinggi pendidikan, makan ia akan mudah menerima hal baru dan akan mudah menyesuaikan dengan hal baru tersebut. Responden yang berpendidikan tinggi lebih mampu menggunakan pemahaman dalam merespon kejadian secara adaptif dibandingkan kelompok responden yang berpendidikan rendah. Semakin tinggi pendidikan seseorang maka semakin rasional keputusan yang diambil. Kondisi ini menunjukkan respon cemas cenderung pada responden yang berpendidikan rendah karena rendahnya pemahaman terhadap kejadian sehingga membentuk persepsi yang menakutkan dalam merespon kejadian. Semakin tinggi tingkat pendidikan seseorang akan lebih mudah dalam menerima informasi tentang keadaannya. Sehingga seseorang akan lebih mengerti tentang cara penatalaksanaan terhadap tindakan dalam mengendalikan kecemasan dengan mekanisme koping yang efektif. Sebaliknya jika pendidikan rendah maka sulit menerima atau merespon kecemasan yang sedang dialami.

Penelitian ini diketahui bahwa perbedaan rata-rata skor indeks kecemasan pre operasi sebelum dan setelah diberikan tindakan relaksasi nafas dalam pada responden yang dilakukan pengukuran 1 hari mengalami penurunan ratarata indeks kecemasan sebanyak 4,00, pada responden yang dilakukan pengukuran 2 hari mengalami penurunan rata-rata indeks kecemasan sebanyak 6,18 , dan pada responden yang dilakukan pengukuran $>2$ hari mengalami penurunan rata-rata indeks kecemasan sebanyak 7,00. Hal ini dapat kita simpulkan bahwa semakin lama tindakan relaksasi nafas dalam dilakukan, akan semakin menurunkan indeks kecemasan.

Hasil penelitian disimpulkan bahwa terapi relaksasi nafas dalam berpengaruh terhadap penurunan tingkat kecemasan pada pasien pre operasi bedah abdomen di Ruang Bedah RSUD Jendral Ahmad Yani Metro Tahun 2017. 


\section{SIMPULAN}

Hasil penelitian yang dilakukan di Ruang Bedah RSUD Jendral Ahmad Yani Metro, diperoleh beberapa kesimpulan, yaitu:

a. Rata-rata skor indeks kecemasan pasien pre operasi bedah abdomen sebelum dilakukan terapi relaksasi nafas dalam didapatkan hasil mean 54,59 yang artinya rata-rata pasien pre operasi bedah abdomen dikategorikan kecemasan sedang,

b. Rata-rata skor indeks kecemasan pasien pre operasi bedah abdomen setelah dilakukan terapi relaksasi nafas dalam didapatkan hasil mean 49,56 yang artinya rata-rata pasien pre operasi bedah abdomen dikategorikan kecemasan ringan.

c. Ada perbedaan rata-rata skor indeks kecemasan sebelum dan sesudah dilakukan terapi relaksasi nafas dalam pada pasien pre operasi bedah abdomen, dengan p-value $(0,000)<\alpha(0.05)$.

\section{SARAN}

a. Tempat Penelitian

1) Diharapkan RSUD Jendral Ahmad Yani Metro lebih meningkatkan kualitas

\section{DAFTAR PUSTAKA}

Asmadi. 2009. Tehnik Prosedural Keperawatan: Konsep dan Aplikasi Kebutuhan Dasar Klien. Jakarta: Salemba Medika.

Kozier, B., Erb, G., Berman, A., \& Snyder, S. J. 2010. Buku Ajar Fundamental Keperawatan: Konsep, Proses, \& Praktik, Ed.7, Vol.1\&2. Jakarta: EGC.

Kusumawati, F., \& Hartono, Y. 2011. Buku Ajar Keperawatan Jiwa. Jakarta: Salemba Medika.

Muttaqin, A., \& Sari, K. 2009. Asuhan Keperawatan Perioperatif Konsep, Proses, dan Aplikasi. Jakarta: EGC.

Notoatmodjo, S. 2010. Promosi Kesehatan Teori \& Aplikasi Edisi Revisi 2010. Jakarta: Rineka Cipta.

Puspita, N. A., Armiyati, Y., \& Arif, S. 2014. Efektifitas Waktu Penerapan Teknik Relaksasi Nafas Dalam Terhadap pelayanan kesehatan yang lebih baik dan bermutu.

2) Penelitian ini diharapkan dapat menjadi informasi bagi tenaga kesehatan yang bertugas di RSUD Jendral Ahmad Yani Metro khususnya Ruang Bedah untuk lebih meningkatkan pelayanan kesehatan dan meningkatkan mutu pelayanan kesehatan masyarakat khususnya pendidikan kesehatan pre operasi teknik relaksasi nafas dalam ini diharapkan dilakukan oleh tenaga kesehatan pada waktu yang tepat agar dapat diterima dan dimengerti oleh pasien.

3) Diharapkan untuk pasien pre operasi dapat melakukan terapi relaksasi secara mandiri disaat ada kecemasan dan dapat menyalurkan informasi kepada kerabat atau saudaranya yang mengalami pre operasi.

\section{b. Bagi Peneliti Selanjutnya}

Diharapkan untuk peneliti selanjutnya dapat meneliti tingkat kecemasan pasien pre operasi menggunakan perbandingan antara terapi relaksasi nafas dalam dengan terapi yang lainnya seperti distraksi, akupuntur, murotal dan lain-lain.

Penurunan Kecemasan pada Pasien Pre Operasi Bedah Mayor Abdomen di RSUD Tugurejo Semarang. Karya Ilmiah S. 1 Ilmu Keperawatan.

Rafsanjani, H. 2015. Pengaruh Terapi Relaksasi terhadap Tingkat Kecemasan Pasien Pre Operasi di Ruang Bedah RSUD Dr. H. Abdul Moeloek Provinsi Lampung.

Smeltzer, S. C., \& Bare, B. G. 2002. Buku Ajar Keperawatan Medikal-Bedah Brunner \& Suddarth. Edisi 8. Vol. 1. Jakarta: EGC.

Stuart, G. W. 2006. Buku Saku Keperawatan Jiwa. Edisi 5. Jakarta: EGC.

Sudarsih, W. 2012. Perbedaan Tingkat Kecemasan Pasien Pre Operasi Appendisitis Sebelum dan Sesudah Diberikan Teknik Relaksasi Nafas Dalam di Ruang Perawatan Rumah Sakit Imanuel Bandar Lampung. 